\title{
CONGENITAL DISPROPORTIONAL CHONDRODYSPLASIA IN PIGS
}

\author{
J. KAMAN, J. DRÁBEK, Z. ŽERT
}

Department of Pathological Morphology and Parasitology; Department of Prophylaxis of Pig Diseases, Animal Breeding and Zoohygiene; Department of Farm Animal Reproduction and Surgery, University of Veterinary Science, 61242 Brno

Received October 29, 1990

\begin{abstract}
Kaman J., J. Drábek, Z. Žert: Congenital Disproportional Chondrodysplasia in pigs. Acta vet. Brno, 60, 1991: 237-251.

In a commercial stock of pigs reared semi-intensively almost 100 animals out of a total of about 800 juvenile pigs exhibited variously intense motility disorders, some very serious, of unclear aetiology, mainly in the pelvic limbs. The clinical symptoms were reminiscent of $\mathrm{Ca}$ and $\mathrm{P}$ metabolic disorders, but increased saturation with these elements did not result in an improvement. With increasing weight the motility disorders of the animals increased to such an extent that they all had to be slaughtered before reaching the proper body mass.

Clinical, X-ray and pathomorphological study of 8 sick animals and two controls revealed the typical signs of disproportional congenital chondrodysplasia; strikingly short limbs as a result of premature closure of growth cartilage, and thus a halt to the longitudinal growth of the long bones of endochondral type, their thickening under the influence of normal continuation of perichondral ossification, extreme dysplasia with characteristic deformation of the epiphyses and the joint sockets, especially in the regions of the joints, which were the actual cause of the motility disorders. The proportions of trunk and head remained unchanged.

As regards aetiology, we suppose this be a hereditary disorder of endochondral development of bones with autosomal recessive heredity.
\end{abstract}

Chondrodysplasia, pathology, joints, bones, hereditary dwarfism, motility disorders, pig

Hereditary dwarfism in various domestic animals has been described by various authors (Dämmrich 1967; 1985; Hámori 1983; Nieberle and Cohrs 1970; Duffell et al. 1985; Jubb et al. 1988). This developmental anomaly was noted in pigs in 1982, apparently for the first time, by Jensen et al. (1982) and was reported by them at the Mexico IPVS congress. A subsequent paper (Jensen et al. 1984) was devoted mainly to the experimental demonstration of its hereditary nature.

In our case, we began in 1983 to note in the juvenile pigs of a farm stock motility disorders of unclear aetiology which seemed almost enzootic. The stock was a medium-sized one, with a basic herd of around 250 sows, using semi-modern methods, and feeding with complete mixtures. The overall zoohygienic and zootechnical standard of the stock was relatively low. The sows included around ten dreeds or combinations. In many of them the origin was unknown or doubtful, since breeding records were badly kept and unreliable. In addition, during a period when there was a lack of suitable sows, juvenile sows from the same herd were used for breeding, without regard to their genetic background.

There was a striking shortness in the legs of the pigs affected, and in the more seriously affected a "dachshund" posture and movement of the limbs. The animals gave the overall impression of disproportionate dwarfs, since the head and the overall body length were unchanged. These disorders had been noted even in sucklings. In juvenile pigs weighing over $20 \mathrm{~kg}$ the problem grew more serious because of the increased load on the limbs. The clinical symptoms of the disease were reminiscent of a breakdown of the $\mathrm{Ca}$ and $\mathrm{P}$ metabolism. Increased saturation with these elements in the affected animals and vitamin $D$ administration did nothing to allievate 


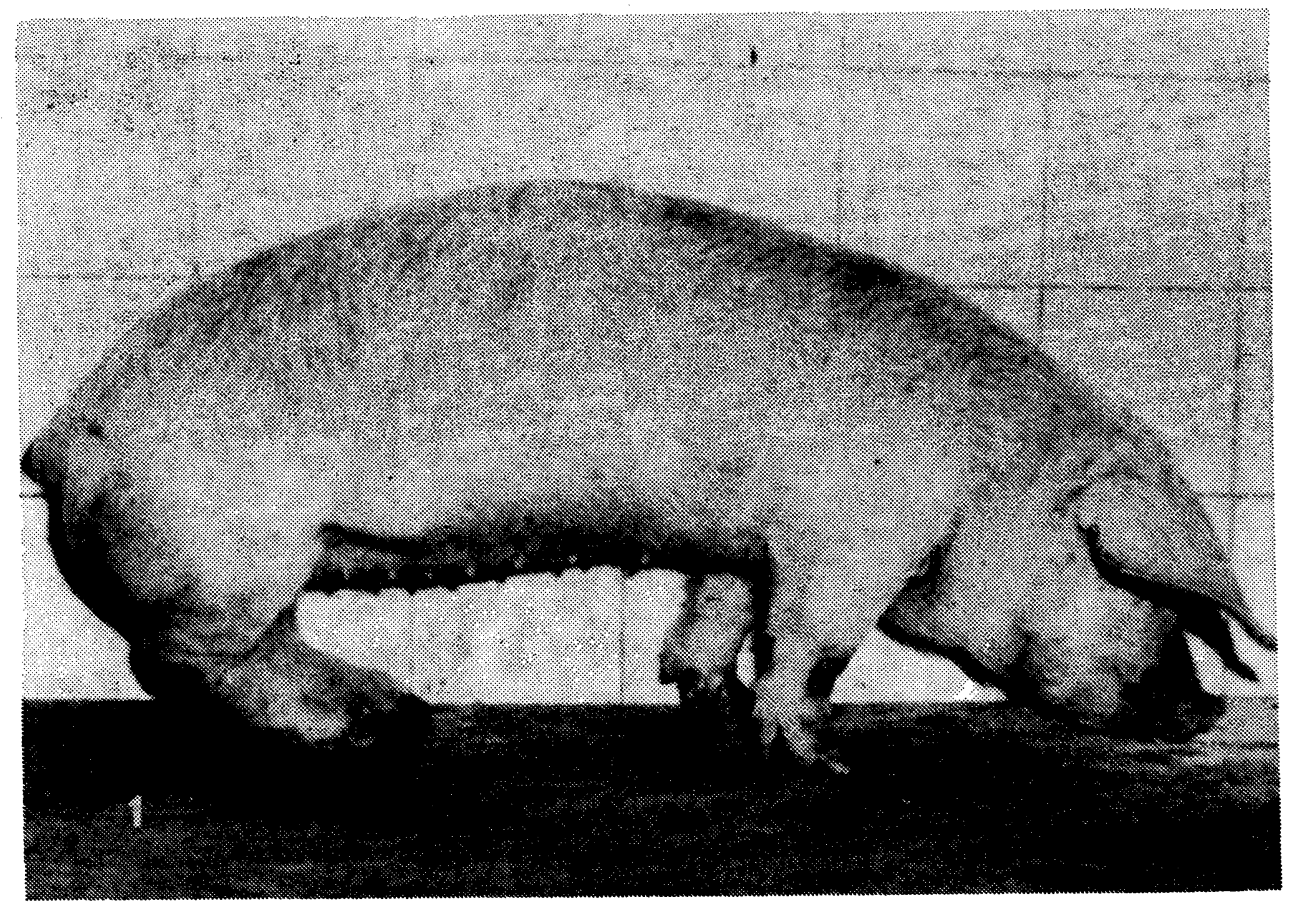

Fig. 1. A serious degree of chondrodysplasia (CHD). Strikingly short limbs placed under body, back arched. The splayed posture of the pelvic limbs indicates dislocation of the femur and incongruity of the knee joint.

the symptoms, however, and when the disease took on epidemic proportions (almost 100 animals out of some 800) six affected pigs were handed over to the Department of Prophylaxis of Pig Diseases, Animal Breeding and Zoohygiene of the University of Veterinary Science in Brno.

We have published partial results in a previous paper (Kaman et al. 1987). The stimulus for a further study of congenital chondrodysplasia was its occurrence early in 1988, though in a more limited extent, in an other medium-large breeding stock.

This study was aimed not only at the nosological definition of the animals studied, but in particular at research into the pathological anatomical picture of the skeleton and the limb joints which give rise to the actual motility disorders and the overall constitution of the body. This aspect is neglected both in the above-mentioned publications of Jensen et al. (1984), and in general.

\section{Materials and Methods}

The experimental group comprised eight pigs with various degrees of disorder, weighing around $20-30 \mathrm{~kg}$, males and females, with two control animals from another stock, weighing the same.

The animals were first of all clinically and radiographically examined. In order to elucidate certain findings some regions were also X-rayed post mortem. Immediately following slaughter muscle samples were taken from individual animals for microscopy. Subsequently, routine pathological anatomical autopsy and microscopic investigation of the internal organs and the CNS were performed by the usual histological methods. Histological sections were stained, as was muscle tissue, by the hematoxylin-eosine (HE) method. Particular attention was paid to the anatomical preparation of the joints of whole limbs in their mutual relations, from the hip or shoulder joint to the toe joints, inclusive. The aim was to ascertain the condition of the articular sockets 
and the content of joint cavities, the overall configuration of joints, deformities in them, and especially deformities in the parts of the skeleton forming large limb joints.

Finally osteological preparations were made from the spine and limbs of the experimental animals by means of maceration in order to make a more objective assessment of the pathological anatomical changes in the skeleton, in particular dubious or unclear X-ray findings.

\section{Results}

Clinical investigation of all animals revealed that their body temperature, heart rate and respiratory rate were within physiological limits, that the affected animals had strikingly short limbs, while the head and overall body length were in proportion to their age. The pigs had good to extreme muscle development, with a tendency to form skinfolds, especially in the gluteofemoral and scapulohumeral regions, as can be seen in the X-rays (Figs. 3 and 5). They had various degrees of disorders, not only faults of locomotion, but also anomalies of posture, from quite mild problems to a condition in which the pig was unwilling to move, and did so with great difficulty when forced to, and even merely maintaining a standing posture was a problem. Some pigs were, with increasing weight, unable to move around or even stand for themselves, and suffered a total collapse of the locomotor apparatus (Fig. 2).

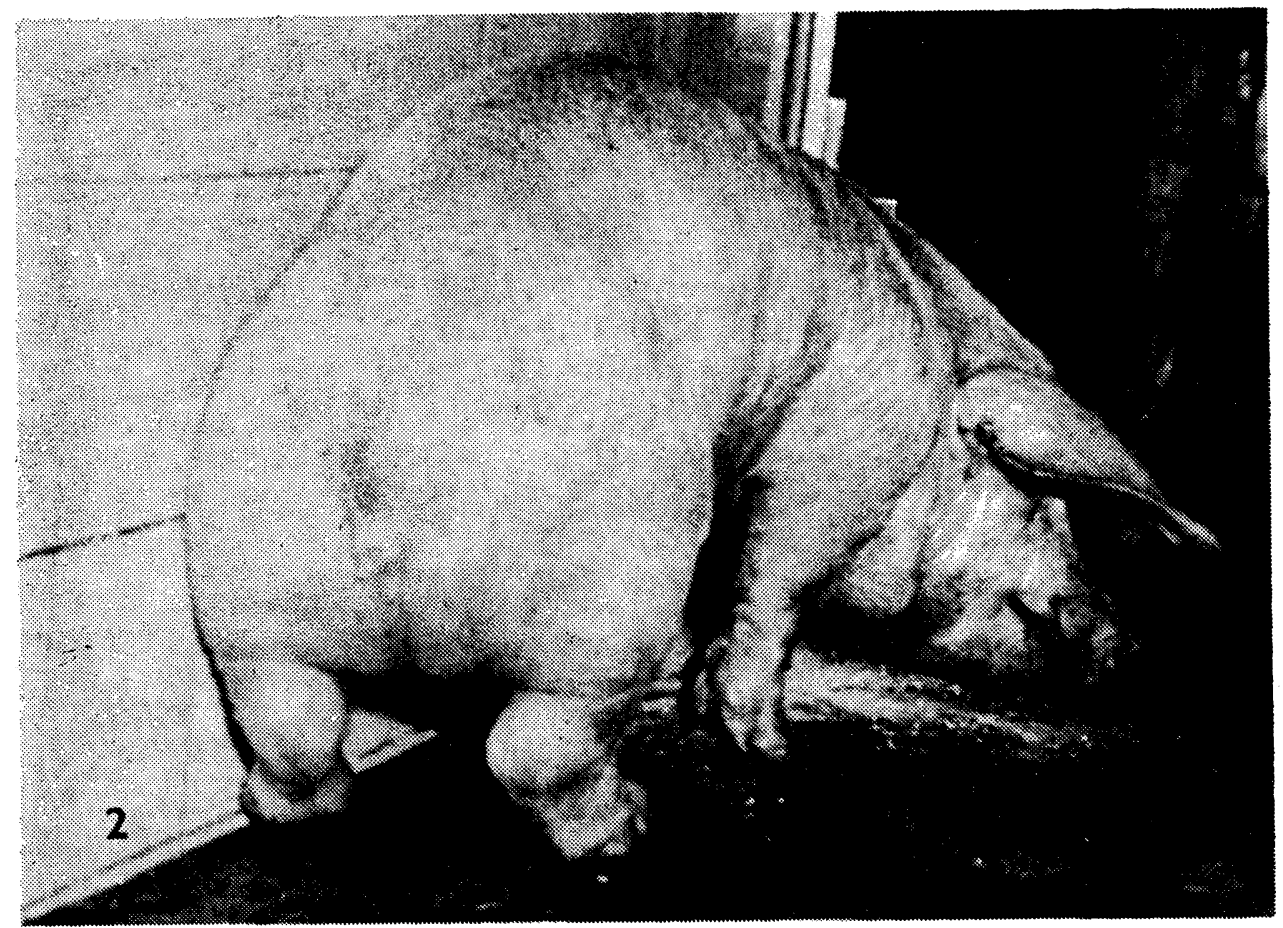

Fig. 2. Very serious CHD. Heavily arched back and subposited limbs, characteristic dachshund posture, collapse of motility. Relatively strong musculature, symptom of lateral deviation of femur and incongruity of joints. 


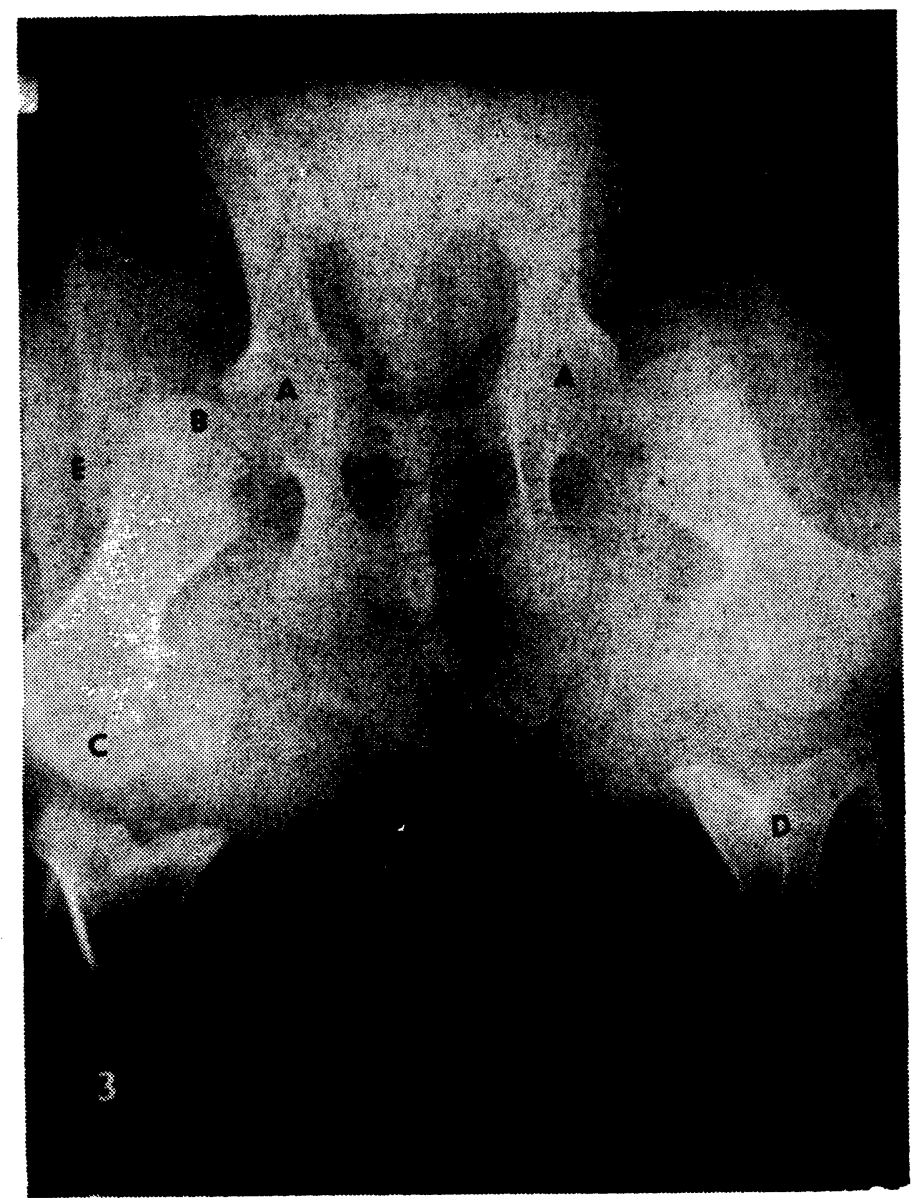

Fig. 3. X-ray of pelvic and femoral region, ventrodorsal projection. Very serious CHD. Growth cartilage is not visible, having become prematurely closed. Serious bilateral dysplasia of the acetabulum (A, A). Left half of pelvic shortened. Thighbones heavily shortened, thickened, heads flattened (B), dislocated from acetabulum, distal epiphyses (C) greatly enlarged, D - seriously dysplastic proximal epiphyses of tibia collapsed in funnel-shape into metaphysis, $\mathrm{E}$ - skinfolds.

The motility problems were mainly localised in the pelvic limbs, the posture and movements of the pigs being reminiscent of those of a dachshund. They had the typical bow-legged posture, discernible in particular from behind, which is characteristic of total luxatio coxae. In spite of the good musculature of this region it was clear from the stance and in particular from movements that the head of the thighbone was in serious cases not in the acetabulum at all, and the femur itself and to some extent also the tibia was laterally splayed (at an angle of some $50^{\circ}$ ), and that the limb was more or less sagittally aligned only from the tarsal region.

Seriously affected animals also exhibited striking anomalies of the thoracic extremities, taking the form of a looseness in the shoulder joint and in particular 


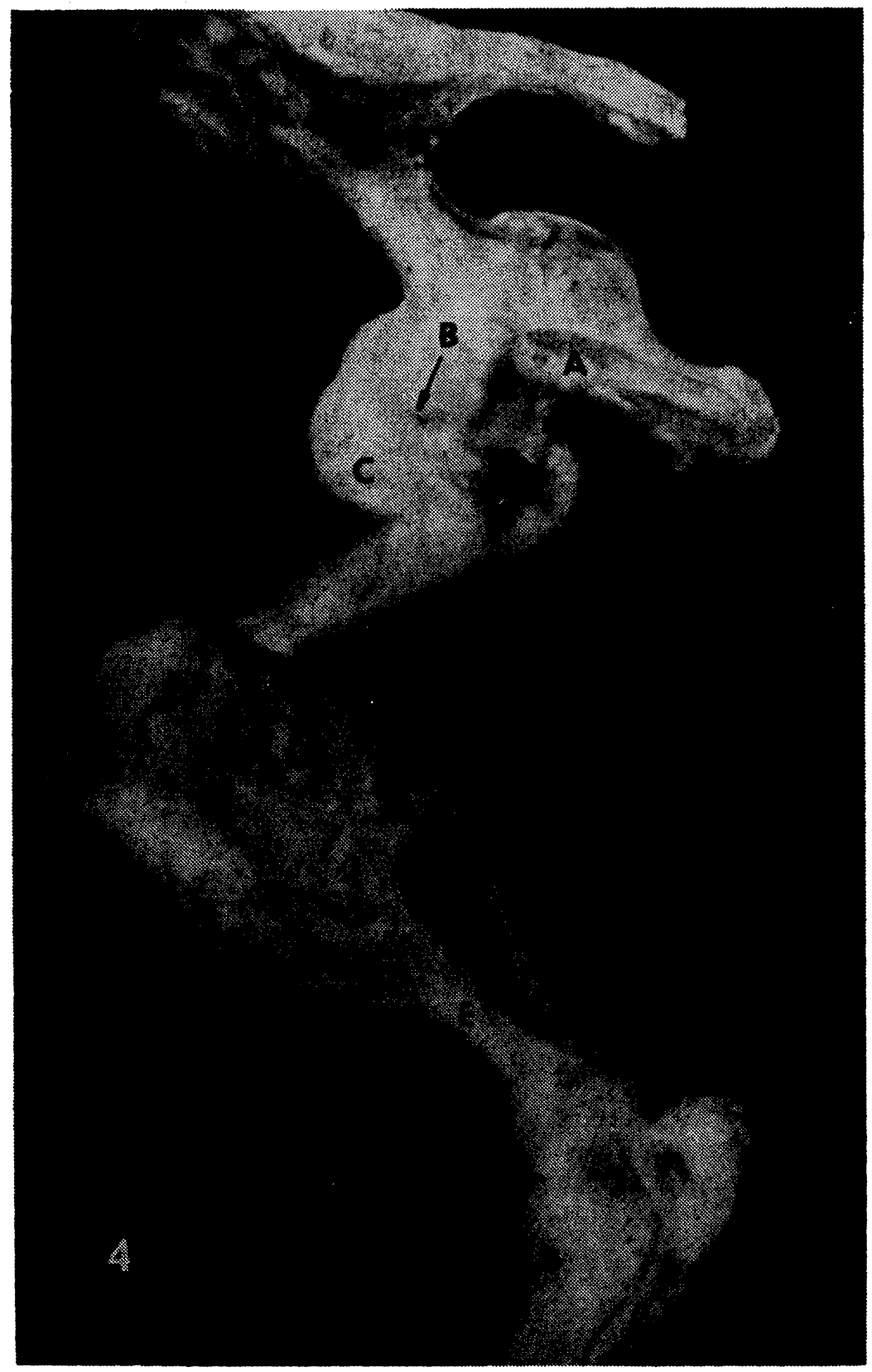

Fig. 4. CHD - joints of left pelvic limbs medially, corresponding to previous picture. A - symphysis pelvis, B - rim of acetabulum (arrow); mushroom-shaped overlap, greatiy enlarged caput femoris, dislocated from acetabulum, D - extreme enlargement of distal epiphysis of femur, E - considerably shortenes tibia with extremely broadened metaphysis $(F)$. 
anomalies in the elbow joint, which was held in slight flexion not only when in motion, but also when stationary, and could not be straightened. These animals moved, where they were still capable of doing so, with their thoracic limbs bent.

$\mathrm{X}$-ray pictures, together with subsequent pathomorphological investigation, showed serious chondrodysplasia, though it varied from case to case, of the skeleton of the extremities; the bones and joints most affected were the stylopodium and the zeugopodium; the bones of the zonopodium, the basipodium and the acropodium, on the other hand, were affected only slightly or not at all. The degree of dysplasia or changes in individual animals corresponded to the intensity of the motility disorder.

As regards the pelvic bones, these were only slightly changed in general conformation and proportionality. The most serious changes were those of the acetabulum or the entire hip joint. In animals with mild degree of affliction the acetabulum was more or less regular in conformation; the rounded caput femoris was for the most part inserted in it, and the growth cartilage of the acetabulum was easily visible in the X-rays and osteological preparations. In proportion to the degree of chondrodysplasia the acetabulum was also dysplastic. In the most serious cases the acetabulum was entirely filled with bone tissue, with the correspondingly deformed caput femoris dislocated completely out of the acetabulum, and the ligamentum capitis femoris entirely destroyed. The dysplastic acetabulum appears quite round in the X-ray picture, with homogeneous density and no clear patches to indicate the acetabular growth cartilage, which in this case is totally closed; the bones are fused, and their longitudinal growth has ceased completely. The projection of the normal acetabulum is oval in the ventrodorsal projection, with clear patches where the growth cartilage is situated. We found dysplasia of the entire hip joint both bilaterally and unilaterally. A time lag between the disappearance of the acetabular growth cartilage on different sides reuslts in a disproportion in lengt between the left and right halves of the pelvis.

In the pathological anatomical picture the X-rays were elucidated and their data supplemented. The autopsied joint was strikingly enlarged as a result of a major increase in volume of the caput femoris, which was mostly completely luxated and quite clearly perceptible through the considerable increase in the size joint capsule. There were no major pathological changes in the soft tissues of the joint, nor in the surrounding tissue. The synovia was clear, unproliferated, yellowy-brown or with a slight admixture of blood. The joint socket was very shallow (scarcely $2 \mathrm{~mm}$ deep), with variations in peripheral shape, sometimes consisting merely of the labrum acetabulare. There was no comparison in size or shape with the head of the thighbone; the two were highly incongruous.

The dysplasia of the femur was marked and characteristic, though in individual cases the intensity of changes corresponded to the degree to which the skeleton in general was affected, especially to the conformation of the hip joint. In serious cases the femur was considerably shortened and thickened (Fig. 3). Diaphyses and metaphyses were both shortened, the latter widening into a club shape, capped by enormously oversized epiphyses, especially the distal one (Fig. 4).

The femur clearly, sometimes strongly, deviated laterally in all cases, at an approximate angle of $45-55^{\circ}$. In one case, where there was a complete collapse of the motoric apparatus, the intravital X-ray showed bilateral femoral dislocation to an almost horizontal position. The metaphysis is heavily thickened and shortened. The epiphysis is much flattened, visibly more perpendicularly oriented 


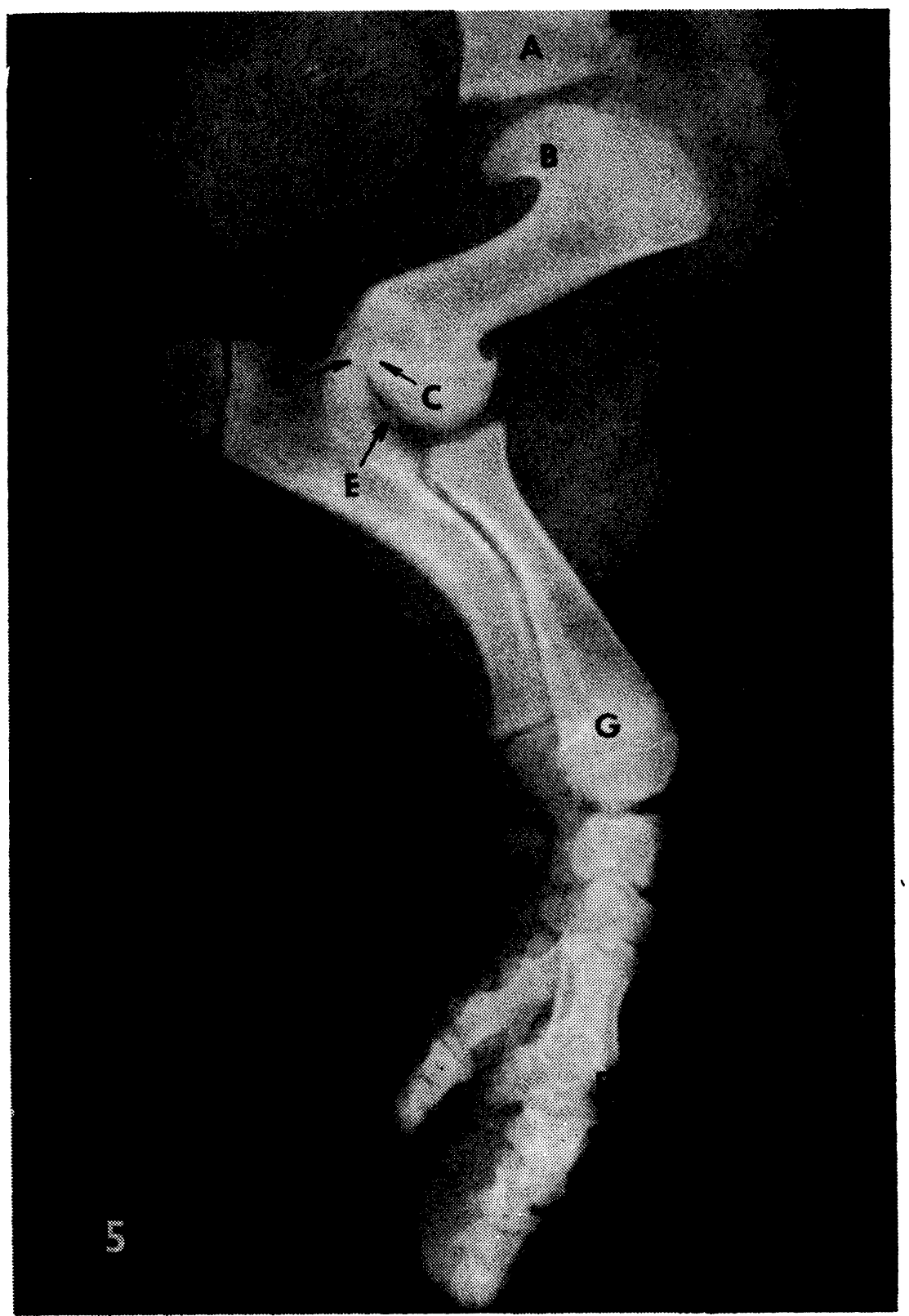

Fig. 5. CHD - X-ray of left thoracic extremity. Angulus scapulae distalis heavily thickened (A), cavitas glenoidales flat to convex, growth cartilage of humerus and radius (G) prematurely closed, that of ulna intact, functional. Humerus considerably shortened and thickened, radius to a lesser extent. Capu humeri (B) greatly thickened, characteristic overhang to almost half way down the diaphysis, $\mathrm{C}$ - protruding part of trochlea runs into fossa olecrani and inhibits processus anconeus (D), E - extremely developed epicondylus medialis, F - bell-like widening of the distal epiphysis of the shortened metacarpi. 
towards the body of the femur, and is lumpy. Sometimes it is less mineralised, similarly as the trochanter major, which protrudes markedly from it. The diaphysis is about $1 / 4$ to $1 / 3$ thicker than controls. There was extreme anomaly of the distal half of the femur. Its metaphysis broadened out sharply in a conical fashion, with an unusual filigree-like pattern on the rim. Into the metaphysis was set in wedge fashion a massively developed, quite atypically formed distal epiphysis whose craniocaudal dimension was at least half the length of the femur. The huge condyles contrasted strongly with the hypoplastic, low-profiled trochlea patellaris, located and running quite anomalously along the epiphysis.

The patella is strikingly more voluminous in the X-rays and in the osteological preparations, and has a less dense matrix. The menisci of the knee joint differed greatly from normal ones, not only in being somewhat deformed, but also in thickness, which was connected with the condition of dysplasia and above all hypoplasia of the proximal epiphysis of the tibia, and with anomalous development and conformation of the distal epiphysis of the femur.

There were also heavily expressed signs of chondrodysplasia in the bones of the shin. The tibia was shortened by $1 / 6$ to $1 / 4$, and thickened by almost $1 / 3$ to $1 / 2$. The fibula was shortened relatively less, thickened evenly along its length, less in the area of the metaphysis and the epiphysis. The metaphysis and epiphysis of the tibia were, on the contrary, extremely broad compared with the diaphysis and unlike the femur were more massively thickened proximally than distally. The thickening of the proximal metaphysis of the tibia is usually considerable, up to $1 / 2$ its normal width, while the distal metaphysis was about $1 / 3$ wider. In this way the tibia acquired a very characteristic goblet shape. Its proximal epiphysis was highly dysplastic, weakly mineralised. Not even in the least serious cases were the ewinentia intercondylaris developed at all. In the more serious cases the joint surface was highly concave in a funnel shape (Fig. 3 ), heavily deformed and highly incongruous, the condyles scarcely protruding over the proximal edge of the metaphysis, into which the epiphysis was conically set, thus determining the shape of the epiphysal cartilage.

Similarly to the proximal epiphysis, the distal epiphysis of the tibia was highly dysplastic and concave in the centre, but in comparison it was less hypoplastic. The cochlea tibiae on the joint surface was usually deeply furrowed and deformed, lumpy in appearance, highly incongruous.

The bones of the hock joint did not exhibit major deviations. X-rays and preparations showed them to be well mineralised. The talus, or its trochlea did not deviate laterally from the overal axis of the limb, but was oriented almost sagittally.

The main metatarsi (III and IV) were shown in the X-rays and the osteological sections to be about $1 / 6-1 / 5$ shorter, and clearly thicker. Their bodies were widened at both ends, distally more strikingly; here the heads of generally more massive metatarsi were set on a bell-like spreading metaphysis. The thickening of the metatarsal bodies of the secondary metatarsi (II and V) was not so marked. This emphasised the sudden and intense widening of the most distal part of the body, with a heavily broadened head, giving metatarsi II and V their characteristic hammer shape.

The proximal phalanges of digits III and IV were of normal length or only slightly shorter, and regular in shape. In spite of a generally symmetrical thickening (by about $1 / 4$ ), the broadening of the bases was more marked, this being an adaptation to the considerable widening of the metatarsi. Still less signi- 


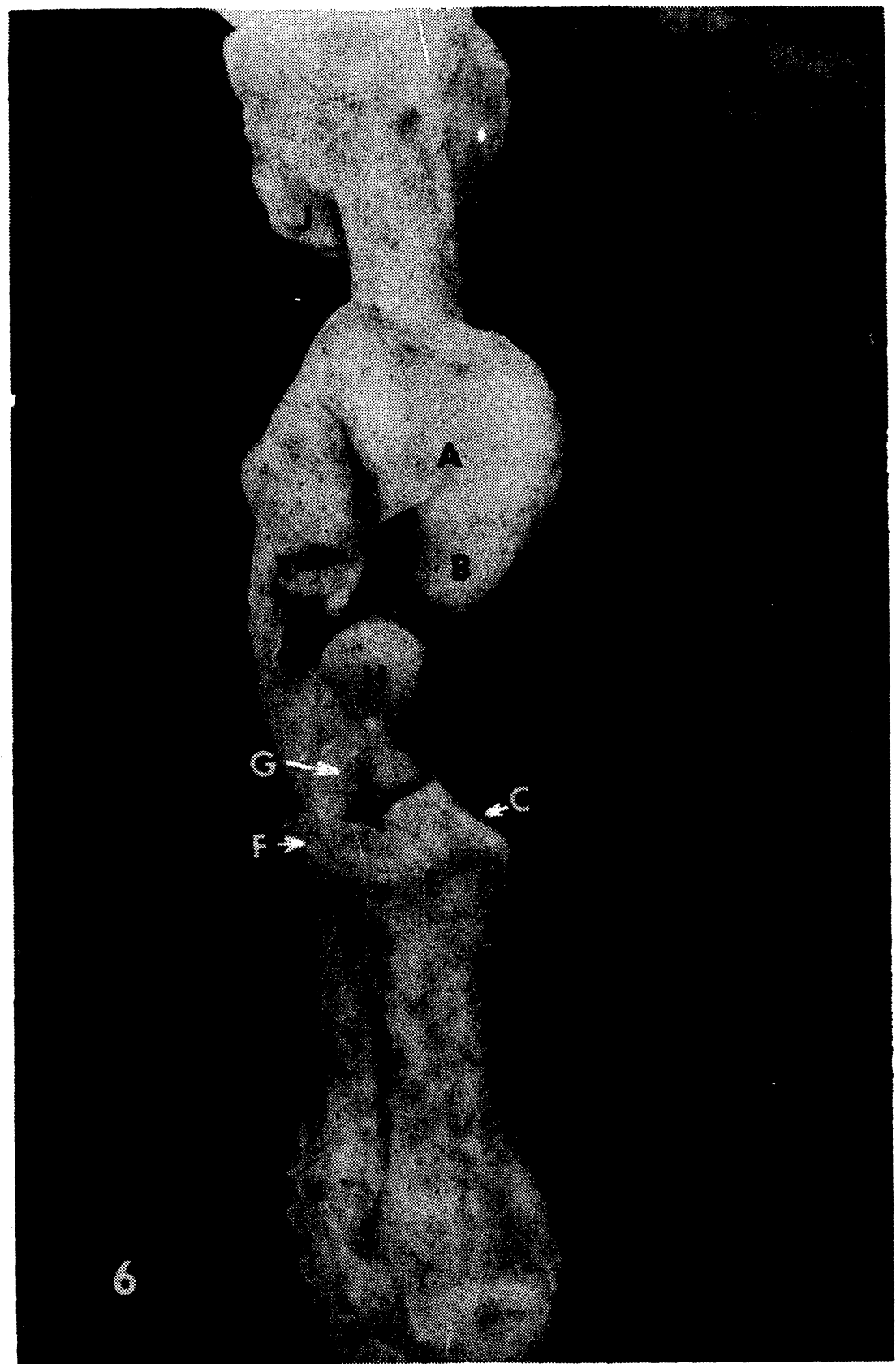

Fig. 6. Open, highly incongruous cubital joint. Humerus is proximally deviated. Radius, and even more so humerus, highly shortened, thickened, epiphyses extremely enlarged. A evenly, distally heavily narrowed sulcus trochleae with sagittal groove, B - enormously developed, laterally deviating epicondylus medialis, o structing the thick, deviated trochlea medially, serious incongruity occurring, new joint surfaces (C), anomalous newly-formed ridge (D), suppression of foveae capitis radii (E), destruction of its joint cartilage (F) and the cartilage covering the processus coronoideus ulnae lateralis $(\mathrm{G})$ and permanent subluxation, $\mathrm{H}$ - deformed processus anconeus, J - caput femoris. 
ficant changes to slight thickening were found in the centre and in particular in the distal segment. The findings in the two secondary toes were analogous.

Changes of the thoracic limbs on the one hand corresponded to the picture of motility disorders and to the changes in the pelvic limbs, and on the other differed from them. While the bones of the zeugopodium of the pelvic limbs, especially the tibia, were among those most affected by dysplasia, the analogous bones of the thoracic limbs were considerably less affected.

The shoulder blades were not very significantly affected either in length or width, even in the most serious cases. Such changes as there were consisted in a visibly more voluminous angulus ventralis scapulae with a more markedly developed tuberculum supraglenoidale and processus coracoideus, and above all various degrees of dysplasia of the cavitas glenoidalis, which was very flat or even convex, very limited in extent, surrounded in periphery by a more lumpy zone.

The most seriously affected bone of the thoracic limbs was the humerus, which was sometimes shorter by more than a third. Though the femur was more strikingly thickened distally, the humerus had both ends extremely developed and their width was sometimes more than half the length of the bone. The most characteristic feature was an unusually short diaphysis and a hugely developed, highly flattened caput humeri, set on the metaphysis at right angles like the head of a toadstool, overlapping to almost half way down the length of the bone. Only a smaller, more rounded section of the articular surface of the head with a smoother surface was articulated with the dysplastic glenoidal cavity; the larger, lumpy part was not in contact with the cavitas glenoidalis scapulae. The tuberculum majus, though very low and poorly mineralised, overlapped the caput humeri, and was more voluminous than normal.

Functionally the most serious anomalies were found at the distal end of the humerus. The trochlea humeri usually deviated strongly in a lateral direction. Its sagittal ridge is absent, as a result of the whole trochlea being pushed aside laterally by the extremely developed medial epicondyle, which is twisted over the sulcus trochleae (Fig. 6). The trochlea has a single sulcus (with a sagittally running, $2 \mathrm{~mm}$ deep pathological groove) which is quite incongruous with the articular surfaces of the proximal epiphysis of the radius und ulna. The joint surface is partly smooth, but mostly lumpy on the periphery. Cranially the trochlea extends in ridge-like manner, anomalously into the fossa radialis. In the intercondylar space it becomes very narrow and extends tongue-like into the fossa olecrani, which it partly blocks, and thus functions as a pathological barrier to the processus anconeus on extension of the cubital joint.

While in the case of the facies articularis carpea of the radius it was in most cases possible to say that the situation was almost normal, in the joint surface of the proximal epiphysis one finds slight to serious anatomical anomalies on the one hand due to dysplasia, on the other to the secondary effect of the serious anatomical anomalies in the distal epiphysis of the humerus. This leads to a suppression of the ridge dividing the fovea capitis ossis radii and on the contrary to the creation of a new ridge with the adjacent face of a pseudorathron on the medial edge of the fovea capitis ossis radii, to destruction of the joint cartilage in the lateral region and on the processus coronoideus lateralis ulnae, to deformation of the processus anconeus and defective development of the joint surfaces of the proximal epiphysis of the ulna, making up the rest of the cubital joint. The result is major incongruity of the joint.

$\mathrm{C}$ arpus as a whole and its individual components were comparable with bones 
from control pigs. Metacarpals and digital skeleton, however, manifested alterations like those on pelvic limbs.

Microscopic investigation of the internal organs (kidney, liver, lungs and beart) and musculature ( $m$. longissimus thoracis, $m$. gracilis, $m$. semimembranosus, $m$. triceps brachii) and rough investigation of the CNS (spinal chord, motor cortex, diencephalon) revealed no changes.

\section{Discussion}

Chondrodysplasia fetalis occurs in man and animals as a dominant, recessive or de novo mutant hereditary defect characterised by faulty development in the cartilaginous tissues of the skeletal base (Dämmrich 1967, 1985). It can affect

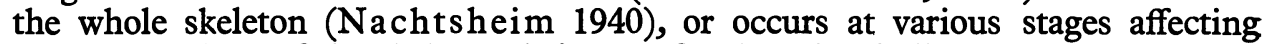
different regions of the skeleton, being confined to the skull, the spine or the extremities (Dämmrich 1985).

The actual cause of this anomaly, which is one of the most frequent hereditary disorders in the development of the skeleton of domestic animals ( $\mathrm{Nachtsheim}$ 1940), is not sufficiently clear. No wonder, therefore, that we find in the literature many synonyms, which are not unusually interchanged at will. A deeper analysis of this question lies outside the scope of our study, and we will confine ourselves to the assertion that the terms used to date, especially achondrogenesis, chondrodystrophia, achondroplasia and achondroplasic syndrome are used as synonyms, but do not always correspond either with each other, or entirely to the facts. They have therefore been placed, as far as domestic animals are concerned, under the umbrella term chondrodysplasias, with the possibility of adding a more precise diagnosis ( $\mathrm{Jubb}$ et al. 1985). We identify with this conception, which takes a broader view of the matter of the developmental defects and corresponds well to our observations. In a previous report (Kaman et al. 1987) we used for the occurrence of dwarfism syndrome in pigs the designation chondrodysplasia fetalis (Dämmrich 1967, 1985). In the present study we reached the conclusion that the supplementary designation fetalis is superfluous where a congenital disorder is concerned, so we have omitted it.

Our research on pigs affected by dwarfism syndrome showed that the basis of the anomalous development and deformities of the skeleton of the extremities is variously intensive defects in the region of growth zones, and the premature cessation of growth, which is easily diagnosed by X-rays. This does not relate only to long bones, but also to flat ones (the pelvis and the scapula). Perichondrial ossification and growth outwards took place normally. The result was various degrees of shortening and thickening of bones compared with controls. The bone musculature and skin develop normally. This disproportion gives rise to pigs which may appear excessively muscular, and the formation of skinfolds on the limbs may occur.

The fact that only the limbs were affected and the remaining body proportions, namely dorsal and head length, were normal, meant that the animals exhibited the typical symptoms of the chondrodysplastic dwarfs first recorded by Jensen et al. (1982) in the breed Danish Landrace. By means of a genetic experiment (Jensen et al. 1984), by the inbred crossing of chondrodysplastic sows with normal boars, they obtained dwarfs analogous to those occurring spontaneously. They deduced from the experiment that this was a disease (development defect) 
with simple autosomal recessive heredity, with a low incidence, and most probably occurring in connection with inbreeding. Their results correspond with our findings of the spontaneous occurrence of disproportionate chondrodysplasia in pigs, as regards both the numerical incidence, possible inbreeding, the fact that both sexes were affected, and the temporary occurrence; the disease was eliminated after breeding practice was improve 1 . The parents were phenotypically normal. We suppose that in our case it may also have been a case of the autosomal recessive heredity of the disease described.

Though the phenotype of disproportionate chondrodysplasia is generally very constant and easily diagnosed, the disease escaped notice among neonates. Similar experience was shared by Subden et al. (1972) in neonatal pups. Its diagnosis was, however, detectable by X-ray at that time. Jensen et al. (1984) observed in piglets produced by genetic experiment the first signs of chondrodysplasia - very loose attachment of limbs to the body - at the age of only two weeks. In commercial stocks the disease was first recorded in juvenile pigs, when with increasing weight disorders of motility increased rapidly (Kaman et al. 1987). The pigs tried to compensate for the pathological condition by positioning their limbs, giving rise to functional, later also the suggestion of pathological, kyphosis. The macrophenotypical effect of this stage of the chondrodysplastic syndrome was reminiscent of rachitis, from which it can be distinguished radiologically and clinically.

Motoric disorders always accompany chondrodysplasia. It is not unusual for them to result in a complete breakdown of motility (Mather 1956; Fletch et al. 1973; Subden et 1972; Jensen et al. 1984; Dämmrich et al. 1985; Duffell et al. 1985; Kaman et al. 1987). We arrived at the conclusion that it is caused by incongruity of the large joints of the limbs of various degrees or total, due to serious pathological anatomical deformations of the socket and epiphysis of those joints. The methods of diagnosis of chondrodysplasia (clinical, radiological) are usually directed towards ascertaining the main symptoms, i.e. shortening of the long bones of the limbs and changes in the epiphysis. In this manner it is not possible to clarify satisfactorily the anatomical deformation, nor the actual causes of the disorders in motility, particularly where only isolated limbs are investigated (Jensen et al. 1984). It is thus understandable that the authors were unable to express an opinion on the serious changes in the pelvic region, especially to the hip joint or the extremely loose attachment of the limbs to the trunk which they stress. Nor did they gain information on the anomalies depicted in the X-rays of the thoracic limbs. They confined their radiological characterisation to six sentences, and their pathological findings to the statement that they confirm the X-ray picture. The sentence "The metaphyses were unusually wide and mushroom-shaped, overgrowing the epiphyses" does not correspond to the facts, and is illogical. It seems to have arisen from a confusion of metaphyses and epiphyses.

Dysfunction is due as much to the shortening of bones and the excessive size of the epiphyses (Dämmrich 1967) as dysplasia of sections of the long bones of the limbs involved in the formation of the bones. It cannot be said with certainty whether in chondrodysplasia there is an increase in size (Dämmrich 1967) or a decrease in size of the epiphyses (Mather 1956). In the region of the stylopodium there is a general tendency in both the thoracic and the pelvic limbs to an abnormal increase in size of the epiphyses, while in the region of the zeugopodium there is hypoplasia. In both cases there is gradual, but for the most part serious dysplasia with considerable deformation of the articular sections of these 
bones, leading to serious incongruity of the joints in question. In general these pathological changes, and thus also the part they play in the motoric difficulties, were most serious in the regions of the zono-, stylo- and zeugopodium, i.e. in the region of the large joints, while in the distal sections of the limbs the changes and dysfunction were less serious, or did not occur at all. To some extent the region of the zeugopodia of the fibula, and especially that of the ulna, are exceptions, being shortened to a lesser extent or not at all. In view of the close relation between the fibula and the tibia, or the ulna and the radius, and the disproportion growth of these in relation to each other, the fibula, and in particular the ulna, are usually bent in a cranial direction.

The extremely loose joining of limbs to the trunk noted by Jensen et al. (1984) in piglets aged only two weeks, but not further clarified, is due in the case of the thoracic limbs mainly to the flat to convex caritas glenoidalis scapulae and the mushroom-shaped caput humeri, and to the serious dysplasia of the joints of the hip and the pelvic limbs, where the caput femoris (also heavily affected by dysplasia) is partially or totally luxated. The ligamentum capitis femoris is usually interrupted or absent altogether. The hip joint is seriously incongruous. Variously intensive dysplasia occurring at various times affects the acetabular growth cartilage between the bodies of individual pelvic bones, leading to morphologically various asymmetries of the pelvis. Dämmrich et al. (1967) also mention a shortening and narrowing of the pelvis. This is met with less frequently, since a precondition is the premature ossification of all growth cartilage of the pelvic bones in the same period. Dysplasia of the hip joint, though not mentioned at all in the published data, is one of the most serious causes of total breakdown of motility.

Serious incongruity also affects the knee joint, not only as a result of the dysplastic distal epiphysis of the femur, but also and mainly on account of the hypoplastic epiphysis of the tibia, as we demonstrated in the X-rays.

In the thoracic limbs the main cause of dysfunction, apart from the extremely loose shoulder joint already mentioned, is serious deformation of the bone epiphyses forming the cubital joint, which causes permanent subluxation and partial flexion of that joint. The maximum extension is only around $95-100^{\circ}$. Full extension is prevented by the humeral trochlea running tongue-like into the fossa olecrani hurreri, acting as a stop to the beak-shaped process of the ulna.

\section{Kongenitální disproporcionální chondrodysplasie u prasat}

$\mathrm{V}$ užitkovém chovu prasat $\mathrm{s}$ polointenzívní technologif chovu se u téměř 100 jedinců $\mathrm{z}$ cca 800 běhounů objevily různě intenzívní až velmi těžké poruchy motility nejasné etiologie, dominující zejména na pánevních končetinách. Klinické př́iznaky připomínaly poruchy metabolismu $\mathrm{Ca}$ a $\mathrm{P}$. Zvýšená saturace postižených zviŕat těmito prvky nevedla ke zlepšení stavu. S přibývající hmotností zviřat se poruchy motility zhoršily natolik, že všechna musela být předčasně odporažena před dosažením jatečné hmotnosti.

Klinickým, rentgenologickým a patomorfologickým výzkumem 8 nemocných zviřat a 2 kontrol jsme konstatovali typické znaky disproporcionální kongenitální chondrodysplasie: nápadně krátké končetiny $\mathrm{v}$ dủsledku předčasného uzávěru růstových chrupavek, a tím zastavení růstu dlouhých kostí enchondrálního typu do délky, jejich ztluštění vlivem normálně probíhající perichondrální osin̂kace, extrémní dysplasie s charakteristickou deformací epifýz a kloubních jam, přede- 
vším oblastí zono-, stylo- a zeugopodia s těžkými inkongruencemi príslušných kloubů, které byly vlastní prŕčinou poruch motility. Proporce trupu a hlavy změněny nebyly.

Hlavní pozornost jsme věnovali $\mathrm{v}$ literatuře chybějícímu, hlubšímu výzkumu patologickoanatomických deformit skeletu končetinových kloubů ve vztahu k poruchám motility $\mathrm{z}$ nich rezultujících. Fokud jde o etiologii, předpokládáme, že by mohlo jít o hereditární poruchu enchondrálního vývoje kostí s autosomální recesivní dědičností.

\section{Врождённая диспропорциональная хондродисплазия свиней}

В продүктивном свиноводстве с полуинтенсивной технологией содержания появились почти у 100 поросят из 800 бегунов недомогания моторики разной интенсивности вплоть до тяжёлого состояния с неясной этиологией, доминирующие в особенности на тазовых конечностях. Клинические признаки напоминали нарушение метаболизма Са и Р. Увеличение насыщенности упомянутыми элементами не вылилось у пострадавших животных в улучшение состояния. С увеличивающейся массой животных нарушения моторики ухудшились настолько, что всех нужно было перед достижением убойной массы үмертвить.

Исходя из клинического, рентгенологисеского и патоморфологического исследований 8 заболевших и 2 контрольных животных, нами были установлены характерные признаки диспропорциональной врожденной хондродисплазии: необыкновенно короткие конечности в результате преждевременного закрытия ростовых хрящей и, тем самым, преакращения роста в длину костей энхондрального типа, их утолщения в результате нормально протекающей перихондральной оссификации, крайная дисплазия с характерной деформацией эпифизов, и суставных впадин, прежде всего в области зоно-, стило- и зеугоподия с тяжелой инконгруентностью соответствующих суставов, ставших собственной причиной нарушения моторики. Пропорции туловища и головы не менялись.

Основное внимание уделяли отсүтствующему в литературе более тщательному исследованию патолого-анатомических деформаций скелета суставов конечностей по отношению к вытекающим из них нарушениям моторики. Что касается этиологии, то, по нашим предположениям, речь идет о наследственном нарушении энхондрального развития костей с аутосомной рецессивной наследственностью.

\section{References}

DÄMMRICH, K.: Ein Beitrag zur Chondrodystrophia fetalis bei Tieren. Berl. Münch. tierärztl. Wschr., 80, 1967: 101-105

DÄMMRICH, K.: Entwicklungsstörungen des Skeletts. In: Handbuch der speziellen pathologischen Anatomie der Haustiere. IV, 3. Auflage (E. Joest ed.), Paul Parey Verlag, BerlinHamburg, 1985

DUFFELL, S. J.-LANSDOWN, A. B. G.-RICHARDSON, C.: Skeletal abnormality of sheep: Clinical, radiological and pathological account of occurrence of dwarf lambs. Veter. Rec., 117, 1985: 571-576

HÁMORI, D.: Constitutional disorders and hereditary diseases in domestic animals. Akadémiai Kiadó, Budapest, 1983 
JENSEN, P. T.-NIELSEN, D. H.-JENSEN, P.-BILLE, P.: Hereditary disproporcionate dwarfism in pigs resembling chondrodysplasia. Proc. VII IPSV Congress, Mexico, p. 165. Cit. JENSEN et al. 1984

JENSEN, P. T. - NIELSEN, D. H.-JENSEN, P.-BILLE, P.: Hereditary dwarfism in pigs. Nord. Vet. Med., 36, 1984: 32-37

JUBB, K. V. F.-KENNEDY, P. C.-PALMER, N.: Pathology of domestic animals, I., Third ed., Academic Press, Orlando, Florida, 1985

KAMAN, J. -DRÁBEK, J. - ŽERT, Z.: Výskyt chondrodysplasia fetalis u prasat. Veterinářství, 37, 1987: $443-446$

MATHER, G. W.: Achondroplasia in a litter of pups. J. Am. Vet. Med. Ass., 128, 1956: 327-328

NACHTSHEIM, H.: Erbpathologie des Stützgewebes der Säugetiere. In: Handbuch der Erbpathologie des Menschen. Bd. 3/1 (Just, G. ed.), Springer Verlag, Berlin, 1940

NIEBERLE, K.-COHRS, P.: Lehrbuch der speziellen pathologischen Anatomie der Haustiere. T. II, 5. Aufg., G. Fischer Verlag, Jena, 1970

SUBDEN, R. E.-FLETCH, S. M.-SMART, M. A.-BROWN, R. G.: Genetics of the Alaskan Malamute chondrodysplasia syndrome. J. Heredity, 63, 1972: 149-152 